\title{
Catalan Atlas of 1375 and Hormuz around 1300
}

\author{
Vladimír Liščák ${ }^{\mathrm{a}}$ \\ ${ }^{a}$ Oriental Institute, Czech Academy of Sciences, Praha,Czechia(Czech Republic),vliscak@orient.cas.cz,vliscak@gmail.com
}

\begin{abstract}
In about 1375, Jewish cartographers from Palma (de Mallorca), Cresques Abraham and his son Jehudà, have produced an outstanding work of the Majorcan cartographic school of the fourteenth century, the Catalan Atlas. The atlas contained the latest information on Africa, Asia, and China, therefore it was considered to be the most complete picture of geographical knowledge as it stood in the later Middle Ages. There was also some up-to-date information. One of the most important innovations has concerned the port of Hormuz in the Persian Gulf and its shift from the mainland (Old Hormuz) to the island of Jerun (since then named Hormuz). My paper compares information about Hormuz in the Catalan Atlas with that in the original texts just before and after the relocation of the city and port.
\end{abstract}

Keywords: Mappæ mundi, Catalan Atlas 1375, Medieval Asia, Old and New Hormuz, cartography and textual sources

\section{Introduction}

If the strategic value of the island of Hormuz has always been notable thanks to its position at the entrance of the Persian Gulf, it is not surprising that this location has been the subject of many cartographic representations. Thus, on late-medieval Latin maps legends underlined the extraordinary richness of the emporium, transferred at the beginning of the 13th century from the Iranian coast to the island of Zurūn/Ğarūn, known as Organa ('O $\rho \gamma \alpha v \alpha$ ) already to the ancient Greeks, and now acquired new name of "Hormuz" In the Catalan atlas of Abraham Cresques, dated 1375, "Hormision" appeared as "comensament deles Indies" 1, a pivotal port between East and West. Yet the narrowness of the entrance to the Gulf, seen by the author of this map as a mere extension, without isthmus, of the Indian Ocean, was imperceptible. For many medieval writers, the Persian Gulf had no expression independent of what we know today as the Arabian Sea or the Western Indian Ocean. Strikingly paradoxical, the region of Hormuz, under the sign of the extraordinary commercial success of the city that gave it its name, often appeared devoid of its main geomorphological feature, its position in the strait that came to bear its name.

\section{Hormuz and its situation around 1300}

Hormuz was once a major trading port controlling the strategic Strait of Hormuz (Arabic: Madīi Hurmuz; Persian: Tangeh?ye Hormoz); around 1300 it moved from the Iranian mainland to the nearby island of Hormuz. The dual presence of Ormuz on the coast and on an island would be, in the Catalan Atlas of 1375, a sign of this transition still poorly understood in the West.

\footnotetext{
1 "aquesta ciutat es appellada ormes la qual es comensament deles Indies". [This city is named Ormes and is the beginning of the Indies.]
}

\section{The city-state of Hormuz (Old Hormuz)}

Hormuz (Arabic: Hurmuz; Persian: Hormuz) was one of the most important ports in the Middle East at the time as it controlled seaway trading routes through the Persian Gulf to India and East Africa. The port was built on shore of Strait of Hormuz, a strait between the Persian Gulf and the Gulf of Oman. It was located near modern Mīnāb $\left(27^{\circ} 8^{\prime} 48^{\prime \prime} \mathrm{N}, 57^{\circ} 4^{\prime} 48^{\prime \prime} \mathrm{E}\right)$, the capital of Minab County (Persian: Šahrestān-e Mīnāb), Hormozgan Province (Persian: Ostān-e Hormozgān).

The beginning of the reign of the amirs of Hormuz dates between 1050 and 1100, when Muhammad Dirhem Kub (also Diramku) migrated from Oman to the Iranian coast (Vosoughi 2009, 89-90). The reason for the migration of their merchants and their residents, including Muhammad Diramku and his followers, from the seaports of Oman to the Iranian coast was the decline of commerce in Sirraf (modern Bandar-e Sīraf, $27^{\circ} 40^{\prime} 0^{\prime \prime} \mathrm{N}, 52^{\circ} 20^{\prime} 33^{\prime \prime} \mathrm{E}$ ) in southern Iran and Suhār $\left(24^{\circ} 20^{\prime} 31.2^{\prime \prime} \mathrm{N}, 56^{\circ} 43^{\prime} 47.6^{\prime \prime}\right.$ E) on the northern coast of Oman.

(Old) Hormuz became the capital of an empire which comprehended a considerable part of Arabia on one side, and Iran on the other. The port had captured most of the trade of the Indian Ocean, controlling sea ports on the Arabian littoral of the Northern Gulf: Ra's al-Khaymah, Julfar and al-Bahrayn, as well as the Omani coast. Hormuz was styled then as "no equal on the face of the earth." (Agius 2008, 82)

The twelfth and thirteenth centuries can be considered a time when Hormuz was holding its own while submitting to the regional powers. The Hormuz princes were vassals of the atabegs of Fārs (Persian: Atābakān-e Fārs or Salghoriān), a dynasty of Turkmen origin, or of the rulers of Kermān, depending on the political situation (Floor 2012).

During this period, southern Iran was witness to violent transitions of power accompanied by long wars with the 
objective of gaining control over regional commercial transportation routes (Vosoughi 2009, 92).

\subsection{New kingdom}

With the death of Shahāb ad-Dīn Maḥmūd 'Îsā in 1240s, the era of the old kings of Hormuz came to an end. The reign of Rukn ad-Dīn Maḥmūd Qalhātī (ruled 1243-1277 or $1249-1286)^{2}$, the first amir of the new kings of Hormuz, was the beginning of a new period in the history of the kingdom.

Maḥmūd Qalhātī's rule over Hormuz was contemporaneous with the Mongol attack on Iran. Hulagu Khan (Mongolian: Hülegü qan, Chagatai/Persian: Hulākū xān, Arabic: Hūlākū hā̄n, ca. 1217-1265, ruled 12561265) destroyed the power of the Iranian Ismā'ilis of Alamut in 1256 and established the dynasty of the Ilkhans (Persian: Īlxāniyān, Silsilaye Î̀xān̄̄, Monglian: Hülegü-un Ulus, 1256-1336). This naturally led to weakness of the local governments of Fārs and Kermān. Taking advantage of this opportunity, Maḥmūd Qalhātī was able to stabilize his power and made Hormuz independent (Vosoughi 2009, 92).

At its zenith in thirteenth to fourteenth century, Hormuz was a powerful naval state with a large and active trading fleet and a powerful navy.

\subsection{Moving of the port of Hormuz (New Hormuz)}

In the early fourteenth century, during the reign of Bahä' ad-Dīn Ayāz (1293-1311), the port of Hormuz shifted to the island of Ğarūn and enjoyed a primacy that lasted for more than two centuries and encompassed virtually the whole Gulf. At least part of its wealth derived from the old port of Hormuz $\left(27^{\circ} 8^{\prime} 48^{\prime \prime} \mathrm{N}, 57^{\circ} 4^{\prime} 48^{\prime \prime} \mathrm{E}\right)$, located "a farsakh ${ }^{3}$ from the sea" on the Mīnāb river (Polo 1993, 121; Whitcomb 2009, 78).

Because of continued Chagatai (Mongolian) incursions against Southeast Iran, Ayāz decided to move the entire population and its possessions to the small island of Jarun, which he bought from the Fārs rulers (Spuler 1952, 118, 122-127; Wilson 1959, 102-104).

This transfer resulted in the inauguration of a new era in the economic life of the amirs of Hormuz. From then on, in order to benefit from the enormous transit profits, the amirs used their merchant navy to steer the passage of ships toward island of Ğarūn, henceforth known as Hormuz (Persian: Jazīre-ye Hormoz) (Polo 1993, 110; Vosoughi 2009, 93).

A new town was built on the northern tip of Ğarūn Island, which was called New Hormuz for a few years to distinguish it from the old town on the mainland $60 \mathrm{~km}$ away, until this fell into ruins.

By moving the port Hormuz to new location, the Kingdom of Hormuz could control the trade routes to

\footnotetext{
${ }^{2}$ Cf. Polo (1993), 121; Vosoughi (2009), 92, 100.

${ }^{3}$ Farsakh (Arabic: farsah) was a Medieval Arabic unit of distance originated in Persia (Persian: farsang, Middle Persian: frasang, Ancient Greek: $\pi \alpha \rho \alpha \sigma o ́ \gamma \gamma \eta \varsigma$ parasángēs, Latin: parasanga). Its length was about 6 kilometres.
}

mainland Iran: Kermān, Yazd, Shīrāz, Kāshān and Tabrīz. (Agius 2008, 82)

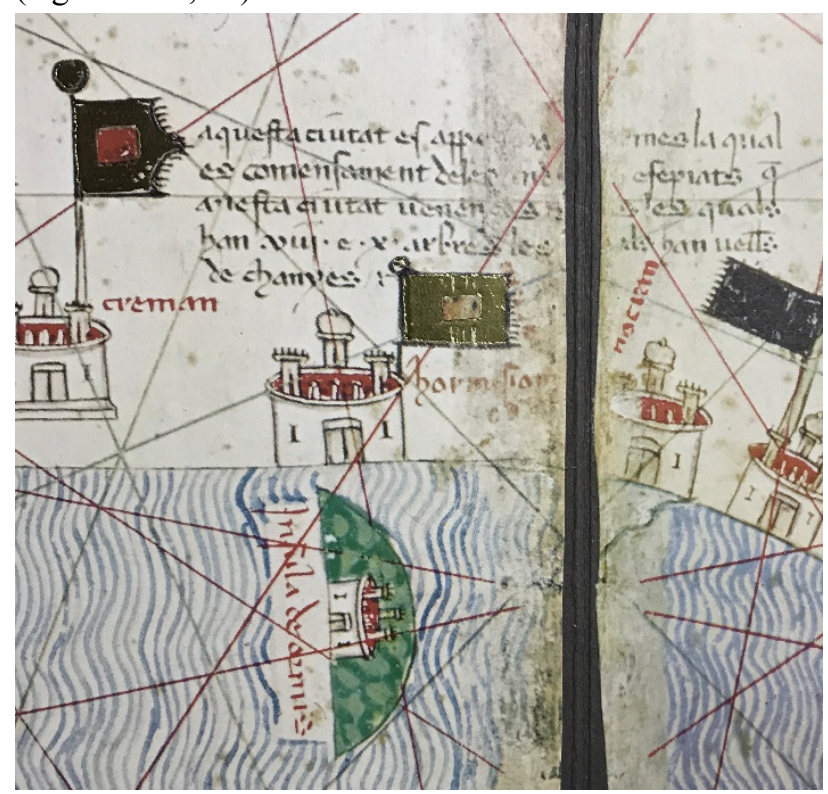

Fig. 1 Port of Hormuz (Hormision) and Island of Hormuz (Insula de Ormus) in the Catalan Atlas

\section{Marco Polo and Hormuz}

Marco Polo (1254-1324), together with his father Niccolò (1230-1294) and uncle Matteo (or Maffeo, 1230-1309), has visited the port-city of Hormuz twicein 1272, in his outward journey, and in 1293 in his return journey. In the first case, something - perhaps the 'deadly' Indian Ocean dhows, the length of the voyage, the need to wait for the monsoon to turn, or all three-clearly changed their mind (Polo 1993, introduction, xxiv).

Marco Polo mentions Hormuz several times in his Travels (Franco-Italian: Le Devisement dou monde, Livre des merveilles or Livre de Marco Polo) as Acummasa, Cormos, Cremosa, Cremosor etc. ${ }^{4}$

\subsection{Cremosor}

For the first time we meet the city Hormuz (Cremosor) in his description of Tabriz (Toris) as an important port:

"Il est voir que les homes de Toris vivent de mercandies et d'ars, car il i se laborent maintes dras a or et de soie et de grant vaillance. La cité si en si buen leu 〈que〉 de Yndie et de Baudac et de Mosul et de Cremosor et de maintes autres leus hi vient les mercandies, et iluec vienent maint mercaant latin por acater de cheles mercandies que hi venent des estranges pais." (XXX. Ci devise de la noble cité de Toris, Divisament 2006, 337$338){ }^{5}$

[The fact is that the inhabitants of Tabriz live by trade and crafts, for a great deal of gold and silver fabric of

\footnotetext{
${ }^{4}$ Cf. Milione (2003), Indice ragionato, 606-607; Divisament (2006), 342 (Curmosa), 347 (Cormos), 349 (Cremosa), 577 (Curmosa), 609-611 (Curmos); Milione (2003), 45 (Acummasa), 50 (Cormos), 52 (Cremosa), 275 (Curimasa), 300 (Curmoso, Curmos, Qurmos).

${ }^{5}$ In these quotations I will use the original Franco-Italian version and modern English translation.
} 
high value is woven there. The city is so favourably situated that merchandise is brought here from India and Baghdad, Mosul and Cremosor (Hormuz) and many other places, and many Latin merchants travel here to buy these goods that arrive from foreign lands.] (Polo 2016, 32)

\subsection{Kish and Hormuz (Curmosa)}

When describing "eight kingdoms" of Persia, Marco Polo mentions Hormuz (Curmosa) together with Kish (Persian: Kīsh; $26^{\circ} 33^{\prime} 28^{\prime \prime} \mathrm{N}, 54^{\circ} 1^{\prime} 10^{\prime \prime}$ E) as an important commercial port:

"Les gens de cesti roiames moinent les cavaus que je vos ai dit jusque a Chisi et a Curmosa, que sunt deus cité que sunt sour la rive dou mer d'Endie; et ilu[ec] trovent les mercant que les acatent et les moinent en Yndie et la li vendent si cher cum je voç ai contés." (XXXIII. Ci devise de VIII roiaumes de Perse, Divisament 2006, 342).

[The people of these kingdoms take the horses I have mentioned as far as Chisi (Kish) and Curmosa (Hormuz), two cities on the shores of the Indian Ocean. There they find dealers who buy them and transport them to India, where they are sold for prices as high as I have said.] (Polo 2016, 28)

\subsection{Description of Hormuz}

The description is very detailed, in accordance with the importance of Hormuz Cormos):

Et quant l'en a chevauchés deus jornee, il treuve la mer osiane et sour la rive ha une cité que est apelés Cormos, le quel a port. Et voç di que les mercaant hi vienent de Yndie con leur nes, hi aportent de toutes especeries et pieres presieuses et perles et dras de soie et d'ores et dens d'olifant et maintes autres mercandies; et en cel cité le vendent a les autres homes que puis l'aportent por tute universe monde, vendant a les autres gens. Il est ville de mout grant merchandies; elle a sout soit cités et caustians asseç, elle est chief dou regne. Le roi a a nom Ruemedan Acomat. Il hi a grandisme chalor, car le solei hi est moût chaut; et f est enferme tere. Et se aucun mercaant d'autre pais hi morent, le roi prend tout son avoir..." (XXXVII. Ci devise de la grande clinee, Divisament 2006, 347)

[After riding for two days the traveller reaches the Ocean Sea. Here on the coast is a city called Cormos (Hormuz), which has a harbour. And I can tell you that merchants come here by ship from every part of India, bringing all sorts of spices, precious stones and pearls, silk and gold fabrics, elephants' tusks, and many other products. In this city they sell these goods to other merchants, who then distribute them throughout the world, selling them to others in turn. It is a very important trading centre. Many other cities and towns are subject to it, for it is the capital of the kingdom. Its king is named Ruknuddin Ahmad. ${ }^{6}$ The climate is torrid, owing to the scorching heat of the sun, and it is an insalubrious place. And if a foreign merchant dies here, the king confiscates all his possessions...] (Polo 2016, 28)

\subsection{Additional information on Hormuz}

Insomuch that Marco Polo visited Hormuz second time in his return journey, we can find some new information in the final chapters of Marco Polo's travelogue.

\subsubsection{The power of Hormuz}

First, we can find some information about kings (maliks) of Hormuz in the chapter on Qalhāt (Calatu; 22 $44^{\prime}$ $39.98 \mathrm{~N}, 59^{\circ} 22^{\prime} 30^{\prime \prime} \mathrm{E}$ ), which formerly was subject to Hormuz, but during Marco's visit was already under new rulers, coming from Qalhāt (see above):

"Calatu est une grant cité qe est dedens le [g]ouf que encore est apellé Calatu; et est loigne de Dufar miles VIc ver maistre. Ell'est une noble cité sor la mer. Il sunt saraçin que aorent Maomet. Il sunt sout Cormos; e toutes les foies que le melic de Cormose a ghere con autre plus poisant de lui, il s'en vient a ceste cité, por ce que mout est fort et en fort leu, si que il ne doute puis de nul... E mantes foies en a le melic de ceste cité grant pa[t] dou soudan de $\mathrm{C}[\mathrm{h}]$ ermain cui il est soutpost: car, quand cel soudan met aucu(n) dasio au melic de Curmos, ou aucun autre de sez frers, et cesti ne le velent doner, e le soudan hi tramest ost por elz esforcer, il se partent de Curmos et entrent es nes e s'en vienent a ceste cité de $\mathrm{Ca}$ [latu] et iluec demorent, et ne laissent passer nulle nes; dont le soldan de $\mathrm{C}(\mathrm{h})$ [er]main en a trop grant domajes. Et por ce convient que il face pes au melic d[e] Curmos e ne li toit pas tant monoie com il li demandoit. Et encore voç di que ceste melic de Curmos a un castiaus que encore est plus fort que la cité et miaus destraint le gof e la mer..." (CXCVII. Ci devise de la cité de Calat[u], Divisament 2006, 608-609)

[Calatu (Qalhāt) is a large city lying inside the gulf of the same name, about 600 miles north-west of Dufar (Dhofar). It is a splendid city built on the shore. The people are Saracens who worship Muhammad. They are subject to Hormuz; and whenever the malik of Curmos (Hormuz) is at war with neighbours more powerful than himself he takes refuge in this city, because it is so strongly built and situated that once inside, he is not afraid of anyone... The malik of this city has often taken advantage of this to exert a powerful influence over the sultan of Kerman, to whom he is subject. For sometimes, when the sultan slaps a tax on the malik of Curmos or one of his brothers which they refuse to pay, he dispatches an army to force them to comply; they then take to the ships and leave Curmos for this city of Calatu, where they stay, preventing any ships from passing, until the losses suffered by the sultan of Kerman mount so high that he finds it convenient to make peace with the malik of Hormuz by moderating his demands for money. I can also tell you that the malik of Hormuz possesses a castle that is even stronger than this city and commands the gulf and the sea even more effectively...] (Polo 2016, 300)

\footnotetext{
${ }^{6}$ He must be Rukn ad-Dīn Maḥmūd Qalhātī (Polo 2016, 369, n.
} 59). 


\subsubsection{Additional chapter on Hormuz}

Following this text, a new chapter dedicated to Hormuz (Curmos), was added: ${ }^{7}$

"Curmos est une grant cité et noble, qui est sor la mer. Il ont melic et ont plusor cités e castiaus sout soi; il sont saracinç que aorent Maomet. Il hi a molt grant chalor, e por le grant chalor qu'il hi a, il ont ordree lor maison a ventier, por recoire le vent; car de celz part dont le vent vente, et il [hi] metent le ventier, e font aler le vent en lor maison; e ce font il por ce que il ne poent sofrir le grant calor qui hi a. Mes plus ne voç en conteron por ce que noç vos en contames en nostre livre en arieres, e de cest e de Quis et de $\mathrm{C}\langle\mathrm{h}$ 〉[er]main, mes por ce que nos alanmes por autres voies, il noç convient encore retorner ci..." (CXCVIII. Ci devise de la cité de Curmos, Divisament 2006, 610)

[Curmos (Hormuz) is a large and splendid city by the sea. It has a malik and has authority over several cities and towns. The people are Saracens who worship Muhammad. The climate is scorching, and because of the intense heat their houses are fitted with ventilators to catch the wind. The ventilators are set to face the direction from which the wind blows, and the breeze is directed into the house. They do this because they cannot bear the terrible heat in this place. But we will tell you no more about it because we told you about it earlier in our book; the same goes for Kish and Kerman. Because we set out by a different route it is fitting to return to this point...] (Polo 2016, 301)

\subsection{Some more additions}

We can also find additional texts, which contain only some versions, namely $\mathrm{R}$ and $\mathrm{Z}^{8}$ :

"\& caualcano il piu delle volte verso le parti di Reobarle, percio che tutti i mercatanti, che vengono a negociar in Ormus, fin che si auisano, che venghino i mercanti dalle parti de India, mandano al tempo del verno i muli, \& camelli, che si son smagrati per la lunghezza del cammino alla pianura di Reobarle, doue per l'abondanza dell'erbe debbano ingrassarsi..." (Della città di Camandu, che si troua doppo vna discesa, \& della region di Reobarle, \& delli vccelli francholini, \& buoi bianchi con vna gobba, \& della origine delli Caraunas, che vanno depredando. Cap. 14., Ramusio 1559, 7b.)

[... and thus sometimes they ride $<$ for thirty or forty days journeys $>$, 9 and usually towards the direction of Reobar ${ }^{10}$, because all the merchants who come to trade in Curmos, until they learn that the merchants from the parts of Indie are corning, send in the winter time the mules and camels, which are become lean through the length of the journey,

\footnotetext{
${ }^{7}$ This chapter we cannot find in some versions, e.g. in Venetian and Latin translations.

${ }^{8}$ Some of the missing material has survived in Giovanni Battista Ramusio's famous $16^{\text {th }}$-century travel compendium Navigationi e Viaggi (R) and in a Latin $15^{\text {th }}$-century manuscript discovered in Toledo in 1932 (Z). For ms. Z, I use here the edition by A.C. Moule \& Paul Pelliot (1938).

${ }^{9}$ This "for thirty or forty days journeys" is added in ms. Z.

${ }^{10}$ Reobar, Reobarle means Rūdbar $\left(28^{\circ} 0^{\prime} 23^{\prime \prime}\right.$ N, $58^{\circ} 0^{\prime} 9^{\prime \prime}$ E), now a city and district in the Kerman Province (Persian: Ostān-e Kermān) in the southeast of Iran.
}

to the plain of Reobar where, through the abundance of grass, they are bound to grow fat...] (Polo 1938/1, 122; cf. Polo 2016, 37)

"Jttem uolumus uos scire quod naues aden. cormos chisci $\&$ aliarum partium que nauigant per mare Jndum propter fragilitatem earum sepius naufragantur. \& si mare illud foret tam turbidum \& austerum. \& turbaretur tam sepe quemadmodum mare de partibus nostris turbatur. nula naues iter suum perficeret/ quin naufragium pateretur..." (Polo 1938/2, ciii)

[Also, we wish you to know that the ships of Aden, Curmos, Chisci, and other parts which sail through the sea of Indie are very often shipwrecked because of their frailty. And if that sea were as troubled and rough and were troubled as often as the sea in our parts is troubled, no ship would finish her voyage but would suffer shipwreck...] (Polo 1938/1, 441; cf. Polo 2016, 297)

All these quotations refer to Old Hurmuz, before the shift to Ğerun Island.

\section{Hormuz in Odoric's Relatio}

Franciscan friar Odoric of Pordenone (ca. 1280-1331) provides the earliest notice (ca. 1320) we have of the new city of Hormuz (Ormes), a city strongly fortified and abounding in costly wares, having no trees and no fresh water, unhealthy and incredibly hot.

"Ex hac India recedens et transiens per multas contratas ad mare occeanum ego veni: prima autem terra quam inveni vocatur Ormes, que est terra multum et bene murata, terra multorum ac magnorum mercimoniorum. In ea tantus et ita immensus calor est..." (Yule and Cordier, eds. 1913, 283; cf. Odorico da Pordenone 2016)

[Quitting this India and passing through many countries, I came to the Ocean Sea. And the first country that I reached is called Ormes, which is a country strongly fenced and abounding in many costly wares. In it is great and immense heat .... (transl. by VL; cf. Yule and Cordier, eds. 1913, 112)

There are big differences in description among various mss. of Odoric's Relatio. Only some of them have mentioned island of Hormuz.

Memoriale toscano has some other additions:

"Poi venimo ad <Ormes>, che è incominciamento dell'India, ed è in capo del mare, la quale terra è in una isola di lungi da terra ferma quasi cinque miglia; nella quale isola non nasce arbore e non v'à acqua dolce, ed è città molto bella e bene murata. Quivi à tanta abundanzia di datteri che per tre soldi n'arebbe l'uomo quanti e' ne potessi portare, ed évi eziandio grandissima abundanzia di pane e di pesce e di carne; ma non è terra sana, ma è pericolosa e d'incredibile <calura $>$." (Memoriale toscano 1990, 99)

We than reached Ormes, which is the beginning of India and is at the head of the sea, whose land is in an island far from the land nearly five miles; in which island no tree is born and there is no fresh water, and it is a very beautiful and well walled city. There is so much abundance of dates that for three dollars there would be as many men as I could carry, and there was a great abundance of bread 
and fish and meat; but it is not healthy land, because it is dangerous and of unbelievable heat. (transl. by VL)

\section{Ibn Bațtūta in Hormuz}

Ibn Batṭūṭa (Arabic fully: 'Abū 'Abd al-Lāh Muḥammad ibn 'Abd al-Lāh 1-Lawātī ț-Ṭanği ibn Baṭūta or Bațtūṭa, 1304-1368/1369), a well-known Berber Muslim Moroccan scholar and explorer, has visited New Hormuz twice, shortly after Odoric, in 1331/1332 and 1341.

\subsection{New Hormuz}

"I travelled next from the land of 'Oman to the land of Hurmuz. Hurmuz is a city on the sea-coast, and is also called Mūghistān. Opposite it in the sea is New Hurmuz, and between them is a sea passage of three farsakhs. We came to New Hurmuz, which is an island whose city is called Jarawn ${ }^{11}$. It is a fine large city, with magnificent bazaars, as it is the port of India and Sind, from which the wares of India are exported to the two 'Irāqs ${ }^{12}$, Fārs and Khurāsān. It is in this city that the sultan resides, and the island in which it is situated is a day's march in size. Most of it is salt marshes and hills of salt, namely the dārābī salt; from this they manufacture ornamental vessels and pedestals on which they place lamps. Their food is fish and dried dates exported to them from alBasra and 'Oman... On this island water is an article of price; it has water-springs and artificial cisterns in which rain-water is collected, at some distance from the city. The inhabitants go there with waterskins, which they fill and carry on their backs to the sea [shore], load them on boats, and bring them to the city. I saw a remarkable thing [there] - near the gate of the cathedral mosque, between it and the bazaar, the head of a fish as large as a hillock and with eyes like doors, and you would see persons going in by one eye and coming out by the other." (Ibn Battuta 2017/2, 400-401)

\section{Hormuz in the Catalan Atlas}

In the Catalan Atlas of 1375, we can find Hormuz both as an island and a city on the sea-coast.

\subsection{City of Hormuz}

The city is called "Hormisiom" and is surrounded by the cities of Kermān (Creman) and Makrān (Nocran).

Above the image of the port of Hormuz we can find a short text. However, its placement at the turn of the leaves $5 \mathrm{a}$ and $5 \mathrm{~b}$ makes the text somewhat unreadable:

"aquesta ciutat es appellada ormes la qual es comensament deles Indies / e sepiats que en esta ciutat uenen les [naus] les quals han $\cdot$ viii $\cdot \mathrm{e} \cdot \mathrm{x} \cdot$ arbres les quals han uells de chanyes :- "

[This city is called Hormuz and there begin the Indies. And you must know that the ships in this city have eight to ten masts and sails made of reed.] (transl. by VL)

\footnotetext{
${ }^{11}$ It means Jarun (Ğarūn), old name of Hormuz (see above).

${ }^{12}$ From the eleventh to nineteenth centuries, the name Iraq referred to two neighbouring regions: Arabic Iraq (Arabic: 'Irāq al-'Arab), modern Iraq, and Persian Iraq (Persian: 'Erāq-e 'Ajamī), western portion of modern Iran (Khūzestān).
}

The city is displayed according to the same pattern as other Muslim cities with the flag. The golden flag with the red square in centre represents the flag of the Ilkhanate of Persia, as we know it from Libro del conosçimiento de todos los reinos $\left(15^{\text {th }}\right.$ century):

"E el emperador de persia ha por señales vn pendon de oro et en medio vna quadra bermeja tal." (Libro del conosçimiento, f. 42a; Espada 1877, 95)

[And the Emperor of Persia has as his insignia a gold flag with a vermilion square in the centre, like this.] (Marino 1999, 90)

Libro del conosçimiento also contains some information on New Hormuz:

"E el su jmperio (= de emperador de Persia) llega desde el mar de sara fasta el mar de jndia do es la ciudad de hormixio..." (Libro del conosçimiento, f. 42a; Espada 1877, 96)

[And his empire ( $=$ of the Emperor of Persia) extends from the Sea of Sara to the Sea of India, where the city of Hormixio is...] (Marino 1999, 91)

\subsection{Hormuz island}

In the Catalan atlas, we can find "Insula de Ormis", displayed as a green island with a city, located in the Persian Gulf near the land of Persia, opposite to the city of Hormuz.

Hormuz island is a mostly barren, hilly island of Iran in the Strait of Hormuz, between the Persian Gulf and the Gulf of Oman, 5 miles $(8 \mathrm{~km})$ off the coast. It has an area of $42 \mathrm{~km}^{2}$ (16 sq mi).

Due to a lack of precipitation, the soil and water are salty. The island is arid, and during the summer months the temperature can rise to over $43{ }^{\circ} \mathrm{C}\left(109{ }^{\circ} \mathrm{F}\right)$. As such, it was not an ideal location for the capital of a principality as all provisions including water had to be brought from the mainland. (See the description by Ibn Batțūta above.)

\subsection{Ships in Hormuz port}

The ships in Hormuz have attracted European travellers, notably by the fact that they do not use iron nails for their construction. For that reason, Marco Polo did not find them safe, as he pointed out in his travelogue:

"Lor nes sunt mout mauvés et ne perisent aseç por ce qu'eles me sunt clavee con agu de fer, mes sunt cuisie de fil que se fait de la scorce de les nocces d'Indie, car il la font macerer et devient come sette de crine de chevas; puis en font fil et en[s]i [c]usent les nes et ne se gaste por l'eive sause de la mer, mes hi dure aseç. Les nes ont un arbres et une voilles et un timon et ne unt cuverte; mes, quant il les ont chargés, il couvrent la mercandies con cuir et desor le merchandie, puis qu'il ont coverte, hi metent les cavaus qui portent en Yndie a vendre. Il ne ont fer por fer agus, et por ce font peron de lign et cuisieure de fil. Et por ce est grant perilz a najere en cele nes, et voç di qu'il e〈n〉 noient mai〈n〉tes, por ce que la mer d'Endie fait grant tenpeste plusor foies." (XXXVII. Ci devise de la grande clinee, Divisament 2006, 348)

[Their ships are very bad, and many of them founder because they are not fastened with iron nails but sewn 
together with thread made from coconut husks. They soak the husk until it becomes like horsehair; then they make it into thread and stitch their ships with it. It does not rot in the salt water of the sea but lasts remarkably well. The ships have one mast, one sail, one rudder, and no deck. Instead, when the cargo has been loaded it is covered with skins, and when it has been protected in this way, the horses that are sent for sale in India are put on top. They have no iron to make nails, so they resort to wooden pegs and sewing with thread. This makes sailing in these ships a deadly endeavour, and I can tell you that many of them sink because the Indian Ocean often whips up into great storms.] (Polo 2016, 38)

The information in the Catalan Atlas about the ships in Hormuz is partly replicated in the text about the ships in the Indian Ocean, which obviously concerns the Chinese ships (see Buchon 1838, 117; Buchon and Tastu 1839/1841/1843, 120; Grosjean, ed. 1977, 86; Palomo $2002,45) .^{13}$

Odoric was also surprised that the ships were only tied up with ropes without the use of a single piece of iron:

"In hac contrata homines utuntur navigio quod vocatur iasse siccum solem spago. In unum istorum navigiorum ego ascendi in quo nullum ferrum potui in aliquo reperire." (Yule and Cordier, eds. 1913, 283; cf. Odorico da Pordenone 2016)

[In this country men make use of a kind of vessel which they call Jase ${ }^{14}$, which is fastened only with stitching of twine. On one of these vessels I embarked, and I could find no iron at all therein.] (Yule and Cordier, eds. 1913, 113-114)

\section{Conclusion}

The merit of the Catalan Atlas lay in the skill with which Cresques and his collaborators employed the best available contemporary sources to modify the traditional world picture. To prove it, I selected-as an examplethe case of Hormuz and his shift from the mainland to the island because of the changed political situation in 1300/1301. The Catalan Atlas has displayed both Old Hormuz (on the mainland) and New Hormuz on island ca. $8 \mathrm{~km}$ ( 5 miles) off the shore (in actual fact New Hormuz was about $60 \mathrm{~km}$ southwest from Old Hormuz). It was noted down in some contemporary sources, from which I have selected the most important: The Travels by Marco Polo, Relatio by Odoric of Pordenone, and The Travels by Ibn Battuta. I have also used additional information from a Spanish source of Libro del conosçimiento de todos los reinos.

\footnotetext{
13 “" sa]piats que aquestes naus son appella[des] nichi e han $\cdot \mathrm{lx}$. coldes decarena e hobren $\mathrm{xxx} \cdot \mathrm{iiij} \cdot$ coldes e menys han [en]cara de $\cdot$ iiij $\cdot$ arbres fins / en $\cdot x \cdot$ e les [lurs] ueles son de canes e de palma" (Catalan Atlas, 5a)

[You must know that these ships are called 'nichi' and have a keel of 60 cubits long and a draught of 34 cubits and at least four but also ten masts and sails of bamboo and palm leaves.] (transl. by VL)

${ }^{14}$ Iasse (jase etc.) originates from Arabic/Persian jahāz, a cargo vessel, small ship type (Agius 2008, 315).
}

\section{References}

Agius, Dionisius A. (2008). Classic Ships of Islam: From Mesopotamia to the Indian Ocean. Leiden and Boston: Brill (Handbook of Oriental Studies/Handbuch Der Orientalistik).

Buchon, Jean Alexandre C. (1838). Notice sur un atlas en langue catalane, manuscrit de l'an 1374, conservé parmi les manuscrits de la Bibliothèque royale sous le numéro 6816, fonds ancien, in-folio maximo. Par Mm. J. A. C. Buchon, membre de l'Académie royale d'histoire de Madrid. [Paris, Imprimerie royale]. (Extrait des Notices et extraits des manuscrits de la Bibliothèque du Roi, Tome XIII, 2e partie.)

Buchon, Jean Alexandre C. and Tastu, Joseph (1839). Notice d'un atlas en langue catalane, manuscrit de l'an 1375, conservé parmi les manuscrits de la Bibliothèque royale sous le numéro 6816, fonds ancien, in-folio maximo. Par Mm. J. A. C. Buchon et J. Tastu. Paris: Imprimerie royale 1839. (Extrait des Notices et extraits des manuscrits, Tome XIV, 2e partie.)

Buchon, Jean Alexandre C. and Tastu, Joseph (1841). Notice d'un atlas en langue catalane, manuscrit de l'an 1375, conservé parmi les manuscrits de la Bibliothèque royale sous le numéro 6816, fonds ancien, in-folio maximo. Par Mm. J. A. C. Buchon et J. Tastu. Paris, Imprimerie royale M DCCC XLI.

Buchon, Jean Alexandre C. and Tastu, Joseph (1843). Notice d'un atlas en langue catalane, manuscrit de l'an 1375, conservé parmi les manuscrits de la Bibliothèque royale sous le numéro 6816, fonds ancien, in-folio maximo. Par Mm. J. A. C. Buchon et J. Tastu. Paris, Imprimerie royale M DCCC XLIII.

Espada, Marcos Jiménez de la (1877). Libro del conosçimiento de todos los reynos e tierras e señoríos que son por el mundo e de las señales e armas que han cada tierra e señorío por sy e de los reyes e señores que los proueen escrito por un franciscano español á mediados del siglo XIV; y publicado ahora por primera vez con notas de Marcos Jiménez de la Espada. [S.1.] [s.n.] Madrid Imp. de T. Fortanet.

Floor, Willem (2012). Hormuz II. Islamic Period, Encyclopædia Iranica, XII/5, 471-476; available online at http://www.iranicaonline.org/articles/hormuz-ii (accessed online at 13 November 2018).

Galera i Monegal, Montserrat (2016). Estudi raonat de les fonts documentals de l'Atles català de 1375. Des del seu inici fins a l'actualitat. Treballs de la Societat Catalana de Geografia, 80 (desembre 2015), 9-66.

Grosjean, Georges, ed. (1977). Mapamundi, der Katalanische Weltatlas vom Jahre 1375. Herausgegeben und Kommentiert von Georges Grosjean. DietikonZürich: Urs Graf Verlag. [facsimile of ms. Espagnol 30, Paris, Bibliothèque nationale française, Richelieu Manuscrits]

Ibn Batoutah (1877). Voyages d'Ibn Batoutah: texte arabe, accompagné d'une traduction, par C. Defrémery et le $\mathrm{D}^{\mathrm{h}}$. B. R. Sanguinetti. Tome deuxième. Paris: Imprimé par autorisation du gouvernement à 
l'Imprimerie nationale. M DCCC LXXVII. Vol. 2. [Data set]. NII "Digital Silk Road" / Toyo Bunko. https://doi.org/10.20676/ 00000219.

Ibn Battuta (2017). The Travels of Ibn Battuta, A.D. 1325-1354. Translated with revisions and notes from the Arabic text edited by C. Defrémery and B. R. Sanguinetti by H. A. R. Gibb. Volume II. London: Routledge. (reprint of edition Cambridge, 1962)

Libro del conosçimiento (entre 1401 y 1500?). Libro del conosçimiento de todos los reinos, tierras y señoríos que son por el mundo y de las señales y armas que han cada tierra y señorío por sy y de los reyes y señores que los proueen (ms.). Biblioteca Nacional de España, Mss/1997 rd.bne.es/viewer.vm?id=0000043289\&page $=1$ )

Liščák, Vladimír (2018). Mapa mondi (Catalan Atlas of 1375), Majorcan cartographic school, and 14th century Asia. Proceedings of the International Cartographic Association, 1, 69, May 2018. (https://doi.org/10.5194/ ica-proc-1-69-2018)

Marino, Nancy F. (1999). El Libro del conoscimiento de todos los reinos (The Book of Knowledge of All Kingdoms). Edition, Translation, and Study by Nancy F. Marino. Tempe, Arizona: Arizona Center for Medieval and Renaissance Studies.

Memoriale toscano (1990). Monaco, Lucio, ed. Memoriale toscano di Odorico da Pordenone. Viaggio in India e Cina (1318-1330). Prefazione di Jeannine Guérin Dalle Mese. Alessandra: Edizioni dell'Orso (Oltramare, 5).

Odorico da Pordenone (2016). Relatio de mirabilibus orientalium Tatarorum. Edizione critica a cura di Annalia Marchisio. Firenze: SISMEL · Edizioni del Galluzzo (Edizione Nazionale dei Testi Mediolatini d'Italia, 41).

Polo, Marco (1407). Le livre de Marc Paule des merveilles d'Aise la grant et d'Inde la majour et la mineur et des diverses regions du monde (ms.). Bibliothèque nationale de France. Département des Manuscrits. Français 2810.

Polo, Marco (1938). The description of the world. [translated and annotated by] A.C. Moule \& Paul Pelliot. London: George Routledge \& Sons Limited, MCMXXXVIII. Vol. 1 a 2.

Polo, Marco (1993). The travels of Marco Polo: the complete Yule-Cordier edition: including the unabridged third edition (1903) of Henry Yule's annotated translation, as revised by Henri Cordier, together with Cordier's later volume of notes and addenda (1920). In two volumes. Volume I. Containing the first volume of the 1903 edition. New York: Dover Publications.

Polo, Marco (2016). The Travels. Translated and with an Introduction and Notes by Nigel Cliff. London: Penguin Classics. (Penguin Classics Hardcover). (also in ePUB format)

Ramusio, Giouan Battista (1559). Marco Polo gentilhuomo Venetiano, delle cose de' Tartari \&
dell'Indie Orientali, con la vita \& costumi di que' popoli, descrittione di que' paesi, \& molte altre cose notabili \& marauigliose: in tre libri descritte, non prima che hora cosi interi \& copiosi publicati. Secondo volume delle Navigationi et viaggi [...]. In Venetia nella Stamperia de Gvinti. L'Anno M D LIX.

Spuler, Berthold (1952). Iran im früh-islamischer Zeit. Politik, Kultur, Verwaltung und öffentliches Leben zwischen der arabischen und der seldschukischen Eroberung 633 bis 1055. (=Akademie der Wissenschaften und der Literatur; Band II). Wiesbaden: Steiner.

Vosoughi, Mohammad Bagher (2009). The Kings of Hormuz: From the Beginning until the Arrival of the Portuguese. Potter, Lawrence G. (ed.): The Persian Gulf in History. New York, Palgrave Macmillan, 89-104.

Whitcomb, Donald (2009). The Gulf in the Early Islamic Period: The Contribution of Archaeology to Regional History. Potter, Lawrence G. (ed.): The Persian Gulf in History. New York, Palgrave Macmillan, 71-87.

Wilson, Arnold T. (1959). The Persian Gulf. An Historical Sketch from the Earliest Times to the Beginning of the Twentieth Century. Third impression edition. London: George Allen \& Unwin.

Yule, Henry and Cordier, Henri, eds. (1913). Cathay and the Way Thither being a Collection of Medieval Notices of China. Translated and edited by Colonel Sir Henry Yule... New edition, revised throughout in the light of recent discoveries by Henri Cordier... Vol. II. Odoric of Pordenone. London: Printed for the Hukluyt Society MDCCCCXIII. 